\title{
Electric vehicle charging strategies including load demand response to address utility grid constraints: a real implementation
}

\author{
David Roszczypala ${ }^{1}$, Christophe Batard ${ }^{1}$, Frederic Poitiers ${ }^{1}$, Nicolas Ginot $^{1}$ \\ david.roszczypala@univ-nantes.fr, Christophe.batard@univ-nantes.fr, Frederic.poitiers@ univ-nantes.fr, \\ Nicolas.ginot@univ-nantes.fr \\ ${ }^{1}$ Institute of Electronics of Rennes \\ Polytech Nantes, Rue Christian Pauc, 44300 Nantes, France
}

\section{Extended Abstract}

The development of electric transport technologies is virtuous in many ways: electric motors have far better yields than combustion motors and contribute to decrease urban local pollution. However they present drawbacks in terms of energy supply. Thus the switch to electric motorization of part of the vehicle fleet leads to an increase in electricity consumption and additional stress on the power grid. Studying the impact of changes in the number of EVs on the French network in the coming years, it appears that the energy required for vehicle charging remains reasonable in comparison with total annual electricity consumption (EVs needs in 2030: $10 \mathrm{TWh}$, total consumption in 2016: $470 \mathrm{TWh}$ ), while power demand can be colossal (several tens to hundreds of GW, for a total installed capacity of $130 \mathrm{GW}$ in 2016) [1].

The expansion of EVs therefore seems possible without a significant increase in our electricity production, but the power demand may be critical if no intelligent charging solutions are set up (intelligent EV load planning). The implementation of scheduling to alleviate the EV load impact usually involves limiting the maximal charging power (leading to increase the charging duration) and delaying charging to off-peak hours. Thus it appears that the scheduling solution tend to conflict with user satisfaction. This paper focuses on a real case of parking lot wherein energy management solutions are employed to take into account grid constraints while trying to meet user satisfaction. It presents a collaborative work that has been conducted between the Institute of Electronics and Telecommunications of Rennes (IETR) and the local utility grid operator, Enedis. An experimental EV parking lot has been developed, including monitoring and remote control of the chargers, and different strategies have been implemented in order to satisfy both user satisfaction and network constraints.

The strategies used are based on stochastic dynamic programming techniques, which have been used for many years in energy management [2,3] and more recently for storage sizing and control [4] and EV scheduling in big fleets with associated renewable energies [5]. Here we apply these principles on a small-size real parking taking into account user's habits and users satisfaction. The real implementation brings experimental results showing the effectiveness of the used methods.

\section{References}

[1] D. Roszczypala and al. "Optimisation de charge de véhicules électriques au sein d'un micro-réseau avec production d'énergie renouvelable, et stockage fixein Symposium de Génie Electrique, Jul 2018, Nancy, France. pp.sciencesconf.org:sge2018:184430.

[2] C-C Lin and al., "Power management strategy for a parallel hybrid electric truck" in IEEE Transactions on Control Systems Technology, 2003

[3] Bilbao and al., "Optimal Energy Management Strategy of an Improved Elevator With Energy Storage Capacity Based on Dynamic Programming" in IEEE Transactions on Industry Applications, 2014

[4] P. Haessig, "Dimensionnement et gestion d'un stockage d'énergie pour l'atténuation des incertitudes de production éolienne," Ph.D. dissertation, École normale supérieure de Cachan-ENS Cachan, 2014

[5] R. Latimier, "Gestion et dimensionnement d'une flotte de véhicules électriques associée à une centrale photovoltaïque: co-optimisation stochastique et distribuée" Ph.D. dissertation, École normale supérieure de Rennes, 2016 